\title{
Perbandingan Aktivitas Antibakteri Ekstrak Bunga dan Daun Beluntas (Pluchea indica (L.) less.) Terhadap Bakteri Staphylococcus aureus
}

\author{
Hida Ilyana ${ }^{1}$, Dwi Bagus pambudi ${ }^{2 *}$, Urmatul Waznah ${ }^{3}$,St. Rahmatullah ${ }^{4}$ \\ 1,2,3,4Program Studi Sarjana Farmasi, Universitas Muhammadiyah Pekajangan Pekalongan \\ *email:dwibagus589@gmail.com
}

\begin{abstract}
Chemical constituents contained in the beluntas plant, including alkaloids, essential oils, flavonoids, phenols and tannins have the ability to inhibit the growth of Staphylococcus aureus bacteria. This research uses maceration extraction method. Thick extracts of flowers and leaves were used with a series of extract concentrations. The purpose of this study was to determine differences in the effectiveness of the ethanol extract of the leaves and flowers of beluntas against the growth of Staphylococcus aureus bacteria. The research method used in this study is the disc diffusion method. Data was collected by measuring the diameter of the clear zone formed in each treatment. Extract concentrations used 5\%, 7\% and $9 \%$. The extracts of flowers and leaves of beluntas (Pluchea indica (L.) Less) have antibacterial activity with a larger zone of inhibition in extracts of leaves of beluntas compared to extracts of leaves of beluntas.
\end{abstract}

Keywords: beluntas : flowers; leaves; extract; antibacterial

\begin{abstract}
Abstrak
Kandungan kimia yang terdapat di dalam tanaman beluntas, diantaranya alkaloid, minyak atsiri, flavonoid, fenol dan tanin memiliki kemampuan untuk menghambat pertumbuhan bakteri Staphylococcus aureus.Penelitian ini menggunakan metode ekstraksi maserasi.Ekstrak kental bunga dan daundigunakan dengan seri konsentrasi ekstrak. Tujuan dari penelitian ini yaitu mengetahui perbedaan efektivitas aktivitas ekstrak etanol daun dan bunga beluntas terhadap pertumbuhan bakteri Staphylococcus aureus. Metode penelitian yang digunakan dalam penelitian ini yaitu metode difusi cakram disk. Pengumpulan data dilakukan dengan cara mengukur diameter zona bening yang terbentuk pada setiap perlakuan. Konsentrasi ekstrak digunakan 5\%, 7\% dan 9\%.Ekstrak bunga dan daun beluntas (Pluchea indica (L.)Less) memiliki aktivitas sebagai anti bakteri dengan zona hambat yang lebih besar pada ekstrak daun beluntas dibandingkan dengan ekstrak daun beluntas.
\end{abstract}

Kata kunci: Beluntas; bunga; daun; ekstrak; antibakteri

\section{Pendahuluan}

Bakteri Staphylococcus aureus adalah jenis bakteri gram positif yang hidup sebagai saprofit dalam saluran membran tubuh manusia, kelenjar keringat, saluran usus dan permukaan kulit $^{[8]}$. Umumnya infeksi piogenik disebabkan oleh bakteri Staphylococcus aureus.Infeksi yang timbul biasanya ditandai dengan terjadinya peradangan, nekrosis serta terbentuknya abses.

Biasanya digunakan antibiotik sebagai agen pencegahan penularan bakteri ${ }^{[4]}$. Namun penggunaan antibakteri secara berlebih dan dalam jangka waktu yang lama dapat mengakibatkan bakteri patogen menjadi resistensi.Sehingga penggunaan antibakteri menjadi tidak efektif.Selain itu, penggunaan antibiotik tergolong cukup mahal. Sehingga perlu dicari alternatif lain yang memiliki potensi sebagai antibakteri 


\section{Prosiding Seminar Nasional Kesehatan 2021 Lembaga Penelitian dan Pengabdian Masyarakat Universitas Muhammadiyah Pekajangan Pekalongan}

yang lebih efektif, efisien dan aman dalam menghambat dan membunuh pertumbuhan bakteri Staphylococcus aureus. Karenanya, banyak orang mulai sadar dengan mulai menggunakan senyawa herbal yang memiliki manfaatsama dengan antibiotik.Salah satu tanaman yang digunakan oleh masyarakat Indonesia sejak dahulu yang memiliki kemampuan sebagai antibakteri adalah tanaman beluntas (Pluchea indica (L.)Less).

Umumnya tanaman beluntas (Pluchea indica (L.)Less) tumbuh liar di tanah keras dan berbatu atau sengaja ditanam sebagai pagar.Sejak lamatanaman beluntas digunakan sebagai obat tradisional.Biasanya beluntas digunakan sebagai obat penghilang bau badan, penurun panas, obat batuk serta obat diare.Dan juga, beluntas memiliki khasiat sebagai antibakteri. Ekstrak daun beluntas memiliki daya antibakteri terhadap Staphylococcus aureus, Bacillus subtilis dan Pseudomonas aeruginosa dengan seri kadar ekstrak 12\%, 24\%, 36\%, 48\% dan 60\%. Dari seri konsentrasi tersebut, didapatkan konsentrasi yang paling optimal sebagai antibakteri terhadap bakteri Staphylococcus aureus adalah konsentrasi $60 \%$ sebesar $1,593 \mathrm{~cm}{ }^{[7]}$.

Namun demikian, pemanfaatan tenaman beluntas masih sebatas menggunakan daunnya saja. Hingga saat ini, belum ditemukan penggunaan bagian tanaman lain dari tanaman beluntas yang digunakan sebagai antibakteri, baik terhadap bakteri Staphylococcus aureus maupun bakteri lainnya. Sehingga penulis tertarik untuk melakukan penelitian dengan judul Perbandingan Aktivitas Antibakteri Ekstrak Bunga dan Daun Beluntas (Pluchea indica (L.)Less) Terhadap Bakteri Staphylococcus aureus.Dengan adanya penelitian ini diharapkan mampu meningkatkan pemanfaatan tanaman beluntas (Pluchea indica (L.)Less) sebagai antibakteri.

\section{Metode}

\section{A. Alat dan bahan}

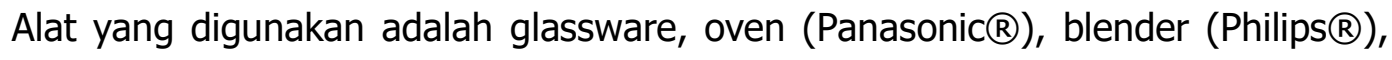
ayakan mesh nomor 40 , timbangan analitik(Ohaus $\AA$ ), moisture balance (Ohaus $₫$ ), jarum ose, jangka sorong, waterbath, rotary vacum evaporator (Heidolph $囚$ ), lemari pendingin (Sharp $\AA)$, incubator (Memmert $\AA$ ), autoklaf (Shenan $\AA$ ), hot plate (MSH280-PRO $囚)$, LAF (Qoalca $囚)$.

Bahan ataupun reagen yang digunakan adalah bunga dan daun beluntas (Pluchea indica (L.) Less), cakram disk, aquadest, etanol 96\%, Mueller Hinton Agar (MHA OXOID $®)$, bakteri Staphylococcus aureus, pereaksi dragendorf, pereaksi mayer, $\mathrm{H}_{2} \mathrm{SO}_{4}, \mathrm{FeCl}_{3}, \mathrm{HCl}$, asam asetat, $\mathrm{NaCl}, \mathrm{BaCl}_{2}$.

\section{B. Prosedur}

\section{Pengumpulan bahan dan determinasi}

Bunga beluntas yang digunakan berasal dari Desa Tegaldowo, Kecamatan Tirto, Kabupaten Pekalongan.Determinasi dilakukan di Laboratorium Biologi Fakultas SAINS dan Teknologi Terapan Universitas Ahmad Dahlan (UAD) Yogyakrta.

\section{Pembuatan ekstrak bunga beluntas}

Serbuk bunga beluntas yang sudah diayak dengan ayakan mesh 40 ditimbang dan dimasukkan dalam toples dan direndam dengan etanol $96 \%$ 


\section{Prosiding Seminar Nasional Kesehatan 2021 \\ Lembaga Penelitian dan Pengabdian Masyarakat Universitas Muhammadiyah Pekajangan Pekalongan}

hingga simplisia terendam dengan lebihan etanol $3 \mathrm{~cm}$ diatas serbuk simplisia. Perendaman sambil sesekali diaduk dan dilakukan selama 3 × 24 jam. Hasil maserasi selanjutnyadisaring menggunakan kain flanel. Residu kemudian diremasarasi dengan pelarut etanol 96\% selama 3 × 24 jam lalu disaring kembali. Maserat dipekatkan dalam vaccum rotary evaporator hingga diperoleh ekstrak kental $^{[10]}$.

\section{Skrining fitokimia}

a) Uji identifikasi alkaloid

Sebanyak 0,5 gram ekstrak dilarutkan dengan $\mathrm{HCl} 1 \%$ kemudian disaring. Fitrat kemudian dibagi menjadi 2 bagian. Bagian 1 ditambah pereaksi dragendorf dan bagian lainnya ditambah pereaksi mayer. Hasil positif uji ditunjukkan dengan terbentuknya endapan merah pada penambahan pereaksi dragendorf dan endapan putih dengan pereaksi mayer $^{[7]}$.

b) Uji identifikasi fenol

Dalam 20 mg ekstrak ditambahkan $\mathrm{FeCl}_{3}$ 1\%.Adanya senyawa fenol menunjukkan terbentuknya warna hijau, merah, ungu dan biru pekat ${ }^{[15]}$.

c) Uji identifikasi flavonoid

Sebanyak $200 \mathrm{mg}$ ekstrak dilarutkan dalam $5 \mathrm{~mL}$ etanol.Selanjutnya dipanaskan selama 5 menit dan disaring.Ditambahkan $5 \mathrm{~mL} \mathrm{HCl}$ pekat dan sebuk $\mathrm{Mg}$ ke dalam filtrat, lalu dikocok hingga homogen. Hasil positif senyawa flavonoid dengan adanya perubahan warna menjadi merah, kuning dan jingga ${ }^{[11]}$.

d) Uji identifikasi saponin

Ke dalam tabung reaksi dimasukkan ekstrak sebanyak 0,5 gram. Kemudian ditambahkan $10 \mathrm{~mL}$ air panas kemudian didinginkan dan dikocok vertikal selama 10 detik.Adanya pembentukan busa setinggi $1-10 \mathrm{~cm}$ yang stabil selama tidak kurang dari 10 menit menunjukkan adanya kandungan senyawa saponin. Penambahan 1 tetes $\mathrm{HCl} 2 \mathrm{~N}$ maka busa tidak hilang ${ }^{[14]}$.

e) Uji identifikasi steroid dan triterpenoid

Ditambahkan 10 tetes $\mathrm{CH}_{3} \mathrm{COOH}$ glasial dan 2 tetes asam sulfat dalam ekstrak.Selanjutnya dikocok dan tunggu beberapa menit.Adanya senyawa steroid ditunjukkan dengan terbentuknya warna hijau kebiruan sedangkan untuk triterpenoid menunjukkan perubahan warna merah atau ungu ${ }^{[13]}$.

f) Uji identifikasi Tanin

Sebanyak 1,5 gram ekstrak dilarukan dalam $5 \mathrm{~mL}$ aquadest. Selanjutnya ditambahkan tetesan larutan besi (III) klorida 10\%.Adanya senyawa tanin menunjukkan perubahan warna menjadi hijau tua ${ }^{[3]}$. 


\section{Prosiding Seminar Nasional Kesehatan \\ Lembaga Penelitian dan Pengabdian Masyarakat Universitas Muhammadiyah Pekajangan Pekalongan

\section{Uji aktivitas antibakteri}

a) Sterilisasi alat

Alat dan media yang akandigunakan dicuci bersih lalu dibungkus dengan menggunakan kertas perkamen (kertas buram).Kemudian dilakukan sterilisasi. Proses sterilisasi dilakukan dengan autoklaf dengan suhu $121^{\circ} \mathrm{C}$ selama 15 menit.

b) Pembuatan media

Dalam Erlenmeyer sebanyak 8,16 gram mediaMuller Hinton Agar (MHA) dilarutkan dalam $240 \mathrm{~mL}$ aquadest. Media dipanaskan hingga mendidih diatas hotplate.Kemudian dilakukan sterilisasi menggunakan autoklaf dengan suhu $121^{\circ} \mathrm{C}$ tekanan $15 \mathrm{lbs}$ selama 15 menit.Media dituang dalam cawan petri kecil sebanyak $30 \mathrm{~mL}$ dan dibiarkan hingga media memadat ${ }^{[12]}$.

c) Pembuatan suspensi bakteri

Bakteri uji yang telah diinokulasi diambil dengan ose steril.Kemudian disuspensikan ke dalam $10 \mathrm{~mL}$ larutan $\mathrm{NaCl} 0,9 \%{ }^{[1]}$.

d) Kontrol positif dan kontrol negative

Kontrol positif yang digunakan adalah blank disk yang telah dijenuhkan dengan $0,1 \mathrm{~mL}$ larutan chloramphenicol $30 \mu \mathrm{g}$ sedangkan kontrol negatif yang digunakan adalah blank disk yang dijenuhkan dengan $0,1 \mathrm{~mL}$ DMSO (dimethyl sulfoxide).

e) Prosedur uji antibakteri

Dalam cawan petri steril dimasukkan mediaMuller Hinton Agar (MHA) cair sebanyak $30 \mathrm{~mL}$, kemudian tungguhingga menjadi padat.Selanjutnya suspensi bakteri dituangkan dan diratakan. Diambil 5 cakram disk dengan menggunakan pinset yang telah dipanaskan diatas api bunsen. Dipipet sebanyak $100 \mu \mathrm{L}$ dari masing-masing seri konsentrasi ekstrak yaitu $5 \%$, $7 \%$, 9\%, DMSO sebagai kontrol negatif dan chloramphenicol sebagai kontrol positif.Selanjutnya media ditandai untuk setiap letak masing-masing konsentrasinya dan cakram disk diletakkan di atas media yang sudah diratakan dengan suspensi bakteri Staphylococcus aureus secara hati-hati menggunakan pinset.Kemudian dilakukan inkubasi selama 24 jam pada suhu $37^{\circ} \mathrm{C}$. Diukur diameter daerah yang terbentuk warna bening menggunakan jangka sorong ${ }^{[9]}$.

\section{Hasil dan Pembahasan}

\section{Hasil}

Tabel 3.1 Rendemen dan kadar air ekstrak bunga dan daun beluntas

\begin{tabular}{ccc}
\hline Karakteristik & Ekstrak bunga beluntas & Ekstrak daun beluntas \\
\hline Bobot simplisia (gram) & 1.000 & 1.000 \\
Bobot ekstrak (gram) & 70,861 & 132,61 \\
Rendeman (\%) & 7,0861 & 13,261 \\
Kadar air $(\%)$ & 0,66 & 0,49 \\
\hline
\end{tabular}




\section{Prosiding Seminar Nasional Kesehatan 2021 Lembaga Penelitian dan Pengabdian Masyarakat Universitas Muhammadiyah Pekajangan Pekalongan}

Tabel 3.2 Hasil skrining fitokimia

\begin{tabular}{ccc}
\hline Golongan senyawa aktif & Ekstrak bunga beluntas & Ekstrak daun beluntas \\
\hline Alkaloid & + & + \\
Fenol & + & + \\
Flavonoid & + & + \\
Saponin & + & + \\
Steroid & - & - \\
Terpenoid & + & + \\
Tannin & + & + \\
\hline
\end{tabular}



Gambar 3.1 Uji aktivitas antibakteri ekstrak bunga dan daun beluntas

\section{Pembahasan}

Hasil determinasi menyatakan bahwa tanaman yang digunakan dalam penelitian merupakan tanaman beluntas dengan nama latin Pluchea indica (L.) Less.Serbuk bunga beluntas memiliki karakteristik serbuk simplisia berwarna kecoklatan dan aroma yang kuat.sedangkan serbuk daun beluntas berwarna hijau kecoklayan dengan aroma yang lebih kuat. Serbuk simplisia yang digunakan untuk pembuatan ekstrak sama banyaknya yaitu 1.000 gram.dari hasil maserasi diperoleh ekstrak sebanyak 70,861 gram (rendemen $7,0861 \%$ ) untuk bunga beluntas. Sedangkan untuk daun beluntas diperoleh ekstrak sebanyak 132,61 gram (rendemen 13,261\%). Dari tabel 1 diperoleh kadar air ekstrak bunga beluntas sebesar 0,66\% dan ekstrak daun beluntas 0,49\%. Hal ini berarti kadar air kedua ekstrak memenuhi syarat yaitu $\leq 10 \%$. Pengukuran kadar air bertujuan untuk menghindari pertumbuhan jamur pada ekstrak. Semakin kecil kadar air yang terkandung maka semakin kecil pula kemungkinan ekstrak terkontaminasi oleh jamur ${ }^{[6]}$.

Dari hasil penelitian menunjukkan bahwa ekstrak bunga beluntas mengandung senyawa alkaloid, fenol, flavonoid, saponin, terpenoid dan tanin.Namun pada penelitian yang dilakukan senyawa steroid tidak terdeteksi.Hal ini dimungkinkan karna senyawa steroid yang tertarik hanya sedikit sehingga tidak terdeteksi. 


\section{Prosiding Seminar Nasional Kesehatan $\mathbf{2 0 2 1}$ Lembaga Penelitian dan Pengabdian Masyarakat Universitas Muhammadiyah Pekajangan Pekalongan}

Dari hasil penelitian diperoleh data, dengan seri konsentrasi ekstrak 5\%, 7\% dan $9 \%$ menunjukkan adanya daya hambat terhadap bakteri Staphylococcus aureus. Pada konsentrasi $5 \%$ ekstrak bunga beluntas menunjukkan zona hambat sebesar 6,4 mm, dengan konsentrasi yang sama pada ekstrak daun beluntas menunjukkan zona hambat sebesar 7,2 mm. untuk konsentrasi $7 \%$ pada ekstrak bunga beluntas memiliki zona hambat sebesar 7,7 mm dan 7,8 mm untuk ekstrak daun beluntas. Sedangkan pada konsentrasi ekstrak $9 \%$ menunjukkan daya hambat sebesar 7,8 mm untuk ekstrak bunga beluntas dan $8,6 \mathrm{~mm}$ untuk ekstrak daun beluntas. Zona hambat yang terbentuk pada semua seri konsentrasi ekstrak bunga beluntas dan daun beluntas termasuk dalam kategori sedang sebagai agen penghambat pertumbuhan bakteri.Sedangkan untuk chloramphenicol sebagai kontrol positif termasuk dalam kategori kuat dengan zona hambat yang terbentuk sebesar $17 \mathrm{~mm}{ }^{[5]}$.Pada DMSO yang digunakan sebagai kontrol negative tidak memiliki zona hambat.Ini karena DMSO tidak memiliki kemampuan dalam menghambat pertumbuhan bakteri.

Dari hasil tersebut, maka dapat disimpulkan bahwa aktivitas antibakteri terhadap bakteri Staphylococcus aureus ekstrak daun beluntas lebih besar dibandingkan dengan ekstrak bunga beluntas. Hasil yang diperoleh menunjukkan bahwa semakin tinggi konsentrasi ekstrak yang digunakan, maka semakin besar pula zona hambat yang terbentuk, baik itu pada ekstrak bunga beluntas maupun ekstrak daun beluntas. Hal ini terjadi karena semakin besar konsentrasi ekstrak yang digunakan maka semakin banyak senyawa yang bersifat sebagai antibakteri yang terkandung di dalamnya.Baik menggunakan ekstrak bunga beluntas ataupun daun beluntas.Senyawa tersebut diantaranya adalah flavonoid, alkaloid, fenol, tannin, terpenoid dan saponin.

\section{Kesimpulan}

Berdasarkan hasil penelitian yang telah dilakukan, dapat disimpulkan bahwa ekstrak bunga dan daun beluntas mengandung senyawa alkaloid, fenol, flavonoid, saponin, terpenoid dan tanin.Berdasarkan hasil uji aktivitas antibakteri, maka ekstrak daun beluntas memiliki efektivitas sebagai antibakteri yang lebih besar dibandingkan dengan ekstrak bunga beluntas. Pada konsentrasi yang sama yaitu $9 \%$, ekstak daun beluntas memiliki daya hambat sebesar $8,6 \mathrm{~mm}$ sedangkan ekstrak bunga beluntas sebesar $7,8 \mathrm{~mm}$.

\section{Referensi}

[1] Afnizar, M., Mahdi, N. \& Zuraidah, 2016. Uji Aktivitas Antibakteri Ekstrak Daun Mahkota Dewa Phaleria macrocarpa Terhadap Bakteri Staphylococcus aureus. Prosiding Seminar Nasional Biotik.

[2] Ahmad, T., Singh, S.B. \& Pandey, S., 2013. Phytochemical Screening and Physicochemical Parameter of Crude Drugs : A Brief Review. International Journal of Pharma Research and Review.

[3] Bandiola, T., 2018. Extraction and Qualitative Phytocemical Screeningof Medicinal Plants : A Brief Summary. International Journal of Pharmacy, 8(1), pp.137-43. 


\section{Prosiding Seminar Nasional Kesehatan 2021 \\ Lembaga Penelitian dan Pengabdian Masyarakat Universitas Muhammadiyah Pekajangan Pekalongan}

[4] Chrystie, Y.k., 2013. Aktivitas Antibakteri Ekstrak Herba Krokot (Portulaca oleracea L.) Terhadap Staphylococcus aureus dan Escherichia coli. Jurnal Lentera Biologi, 2.

[5] Hapsari, E., 2015. Uji Antibakteri Ekstrak Herba Meniran (Phyllanthus niruri) Terhadap Pertumbuhan Bakteri Bacillus cereus dan Escherichia coli. Skripsi. Yogyakarta: Pendidikan Biologi Universitas Sanata Dharma.

[6] Hidayati, D.N., Sumiarsih, C. \& Mahmudah, U., 2018. Standarisasi Non Spesifik Ekstrak Etanol Daun dan Kulit Batang Berenuk (Crescentia cujete Linn). pp.1923.

[7] Manu, R.R.S., 2013. Aktivitas Antibakteri Ekstrak Etanol Daun Beluntas (Pluchea indica L.) Terhadap Staphylococcus aureus, Bacillus subtilis dan Pseudomonas aeruginosa. Calyptra : Jurnal IImiah Mahasiswa Universitas Surabaya, 2, pp.1-10.

[8] Nurwahdaniati, 2014. Aktivitas Antimikroba Ekstrak Etanol 70\% Daun Krinyuh (Chromolaena odorata) Dengan Metode Bioautografi Terhadap Bakteri Staphylococcus aureus. Skripsi. Malang: Fakultas Ilmu Kesehatan Universitas Muhammadiyah Malang.

[9] Rahayu, N., 2019. Uji Aktivitas Antibakteri Ekstrak Etanol Daun Pagoda (Clerodendrum paniculatum L.) Terhadap Pertumbuhan Bakteri Propionicterium acnes, Staphylococcus aureus Dan Staphylococcus epidermidis. Skripsi. Medan: Fakultas Farmasi dan Kesehatan Institut Kesehatan Helvetia Medan.

[10] Ramdan, G., 2019. Isolasi dan Idenitifikasi Senyawa Metabolit Sekunder dari Fraksi Aktif Ekstrak Daun Beluntas (Pluchea indica (L) Less.) dan Uji Aktivitas Inhibisi terhadap Enzim PfMQO. Skripsi. Jakarta: Fakultas Ilmu Kesehatan UIN Syarif Hidayatullah.

[11] Sastrawan, I.N., Sangi, M. \& Kamu, V., 2013. Skrining Fitokimia dan Uji Aktivitas Antioksidan Ekstrak Biji Adas (Feniculum vulgare) Menggunakan Metode DPPH. Jurnal IImiah Sains, 2, p.13.

[12] Satiova, I., 2017. Aktivitas Antimikroba dan Aktivitas Antioksidan Ekstrak Segar Beberapa bagian Tanaman Belimbing Wuluh (Averrhoe Bilimbi).

[13] Sogandi, R., 2019. Identifikasi Senyawa Aktif Ekstrak Buah Mengkudu (Morinda citrifolia L.) dan Potensinya Sebagai Antioksidan. Jurnal Kimia Sains dan Aplikasi, 22(5), pp.206-12.

[14] Tiwari, P., Kumar, B., Kaur, M. \& Kaur, H., 2011. Phytochemical Screening and Extraction : A Review. International Pharmaceutica Sciencia.

[15] Wijaya, D.P., Paendong, J.E. \& Abidjuli, J., n.d. Skrining Fitokimia dan Uji Aktivitas Antioksidan dari Daun Nasi (Phrynium capitatum) dengan Metode DPPH (1,1-difenil-2-pikrilhidrazil). Jurnal MIPA UNSRAT online, 3(1), pp.11-15. 